\title{
Apuntes sobre la esclavitud y la trata de personas en los inicios del Perú republicano (1821-1855)'
}

\begin{abstract}
RESUMEN
En este ensayo se examina la esclavitud republicana como parte de la historia de la trata de personas en el país. Se examinan las condiciones en que se produjo la lucha por la abolición de la esclavitud; la ambigüedad que surgió en el propio Estado al dictarse una abolición parcial, las resistencias que esto suscitó en los terratenientes, los esfuerzos liberatorios por parte de los esclavos y el accionar de los sectores liberales, y su impacto en el espacio público.
\end{abstract}

Palabras Clave: esclavitud; trata de personas; abolición; trabajo forzado

\section{Notes on slavery and human trafficking in early republican Peru}

\section{ABSTRACT}

This essay focuses on republican slavery in the context of the history of traffic of human beings in Peru. We examine the conditions which led to the struggle against slavery, the ambiguity appearing inside the early Peruvian state regarding this issue when slavery was partially abolished, as well as the resistance of landowners to this changes, the efforts of slaves and liberal groups to end the slave system and the general impact on the public space.

KEYwORDs: Slavery; Human trafficking; abolition; forced labour

1 Este trabajo se basa en la investigación sobre esclavitud republicana con miras a una muestra temporal realizada por la autora en el marco de la propuesta "El LUM hacia el bicentenario de la independencia», planteada por Guillermo Nugent durante su ejercicio como director del Lugar de la Memoria. El contenido del texto refleja la interpretación de la autora basada en dicha investigación y en la literatura secundaria existente sobre el tema. Por diversas circunstancias la muestra no pudo realizarse. 
$\mathbf{L}$ a lucha contra la esclavitud ocupa un lugar crucial en la lucha secular por los derechos humanos universales. Su prohibición está inscrita en el artículo $4^{\circ}$ de la Declaración Universal de Derechos Humanos proclamada por la Asamblea General de las Naciones Unidas en 1948: "Nadie estará sometido a esclavitud ni a servidumbre; la esclavitud y la trata de esclavos están prohibidas en todas sus formas». El día 2 de diciembre es el día internacional de la abolición de la esclavitud. La ONU ha suscrito dos convenciones para la supresión del tráfico de personas, pues es justamente este tráfico el que alimenta y permite la esclavitud contemporánea. Actualmente la esclavitud es una práctica ilegal y quienes someten a otros a la esclavitud saben que están infringiendo la ley y atentando contra uno de los derechos humanos básicos: la libertad. Sin embargo, no siempre se consideró algo ilegal. Precisamente, cuando en 1821 se proclamó la independencia del Perú y por tanto la libertad de sus habitantes, los independentistas y la población en general tuvieron que enfrentarse al dilema de la abolición o del mantenimiento de la esclavitud.

\section{Antecedentes coloniales de la esclavitud republicana}

A inicios de la república, la esclavitud era una institución legal, económica y social basada en el derecho de propiedad absoluta de una persona sobre otra; suponía y requería el tráfico o trata de personas para existir y por tanto concebir a las personas como objetos que reciben un valor en el mercado determinado por sus características físicas y su edad. La esclavitud se entendía también como una condición hereditaria. De manera que el hijo de esclavos, era esclavo también. En vísperas de la independencia, varias de estas condiciones habían sido puestas en cuestión por las ideas de la Ilustración, y se habían dado movimientos de gran alcance por los afectados por la esclavitud: la gran revolución de Haití.

Ya a inicios del siglo xIx habían surgido en el virreinato peruano voces que cuestionaban la esclavitud. Por ejemplo, el español residente en Lima Gaspar Rico (1813) había propuesto su abolición paulatina en su folleto Proyecto relativo al comercio, suerte y servidumbre de los esclavos inclinado a su transición opor- tuna a libres durante el tiempo que debe continuar la introducción en territorios españoles. Rico hacía una serie de cálculos del tiempo que debía mantenerse la esclavitud para asegurar ciertos rubros de la economía, y planteaba también el problema de cómo compensar a los dueños de esclavos cuando estos alcanzaran la libertad. Durante la lucha por la independencia, la cuestión de la libertad de los esclavos se plantearía de manera perentoria tanto al bando realista como al patriota por la necesidad de contar con tropas. Sin embargo, una vez obtenida la independencia, pocos países proclamaron la abolición tempranamente: Chile en 1823 y las Provincias Unidas de Centroamérica en 1824. En la mayoría de países hispanoamericanos se dieron leyes como la «libertad de vientres», es decir, se otorgaba la libertad a los nacidos de esclavas a partir de determinada fecha, aunque se estipulaba que debían pese a ello permanecer como sirvientes en casa de sus amos. En líneas generales en el Perú ocurrió este mismo proceso como veremos al analizar la legislación y los debates que se suscitaron en los inicios de la república. La proclamación de la independencia en 1821 no alteró la situación de los esclavos. La sociedad siguió dividida entre libres y esclavos.

El derecho secular además reconocía a los esclavos el derecho a la manumisión. Esta consistía en la posibilidad de comprar su propia libertad o que sus amos se la concedieran sin pago alguno («libertad graciosa»). Hubo unos cuantos esclavos que alcanzaron de sus amos la libertad sin coste. En realidad pocos tenían la posibilidad de ahorrar la suma necesaria para auto-comprarse (una suma de 300 a 400 pesos como promedio), pero hubo algunos que gracias a su trabajo extra como jornaleros lograron reunir lo necesario para liberarse e incluso comprar la libertad de sus familiares. Con el tiempo la manumisión dio origen a un sector social de negros libres, más numeroso en las ciudades que en el campo. También del mestizaje surgieron nuevos sectores de origen africano: zambos, mulatos y pardos. Algunos de ellos fueron también considerados esclavos, y en ocasiones los tribunales tuvieron que decidir sobre su estatus de libertad o esclavitud.

En la etapa colonial, y así sucedió también tras la instauración de la república, los propietarios de esclavos no formaron un grupo uniforme. Los miembros de la alta clase colonial, compuesta por grandes terratenientes, altos funcionarios y grandes comerciantes 
y navieros, algunos de los cuales ostentaban títulos nobiliarios, poseían gran cantidad de esclavos, tanto en sus dominios rurales y empresas como en sus residencias citadinas. Asimismo, había también personas de estratos medios e inferiores que tenían entre uno y cinco esclavos que con su trabajo a jornal les procuraban sustento: artesanos, pequeños comerciantes, rentistas, chacareros, etc. En los conventos había esclavos para realizar todas las labores domésticas y demás trabajos manuales requeridos. Las órdenes religiosas eran poseedoras de gran número de esclavos. Por ejemplo, la Compañía de Jesús, propietaria de extensas haciendas de cańa y de vińa en lo que es el actual departamento de Ica, poseía cientos de esclavos. A raíz de su expulsión en 1776, sus haciendas y esclavos pasaron al control de la Corona, es decir, al estado colonial, que vendió algunas de estas haciendas junto con sus esclavos a miembros de la alta clase virreinal.

\section{La geografía de la esclavitud en el territorio peruano}

A fines del siglo xviII el Virreinato del Perú comprendía siete circunscripciones llamadas intendencias: Lima, Trujillo, Arequipa, Tarma, Huamanga, Huancavelica y Cuzco con un total de 1076122 habitantes. El mayor porcentaje de población correspondía a los indígenas con aproximadamente un 58 por cien del total, seguidos por los mestizos con aproximadamente un 22 por cien del total, y los españoles (en que se incluían los criollos) un 13 por cien. La población libre de color (personas de origen africano: negros, zambos, mulatos, pardos) sumaba poco más de 41000 personas (un 4 por cien), y los esclavos superaban los 40000 .

En el mapa se aprecian las principales localidades con población esclava, por lo que resulta evidente que estaba concentraba en la zona del litoral y sus valles caracterizada por cultivos de alto nivel de comercialización.

Sin embargo, la distribución de la población esclava no era uniforme en las circunscripciones del litoral. Como se aprecia en el cuadro 1, la intendencia de Lima (abarcaba en esa época desde el valle del Santa hasta Nasca) contaba 29763 esclavos y estos representaban un 20 por cien de su población total.

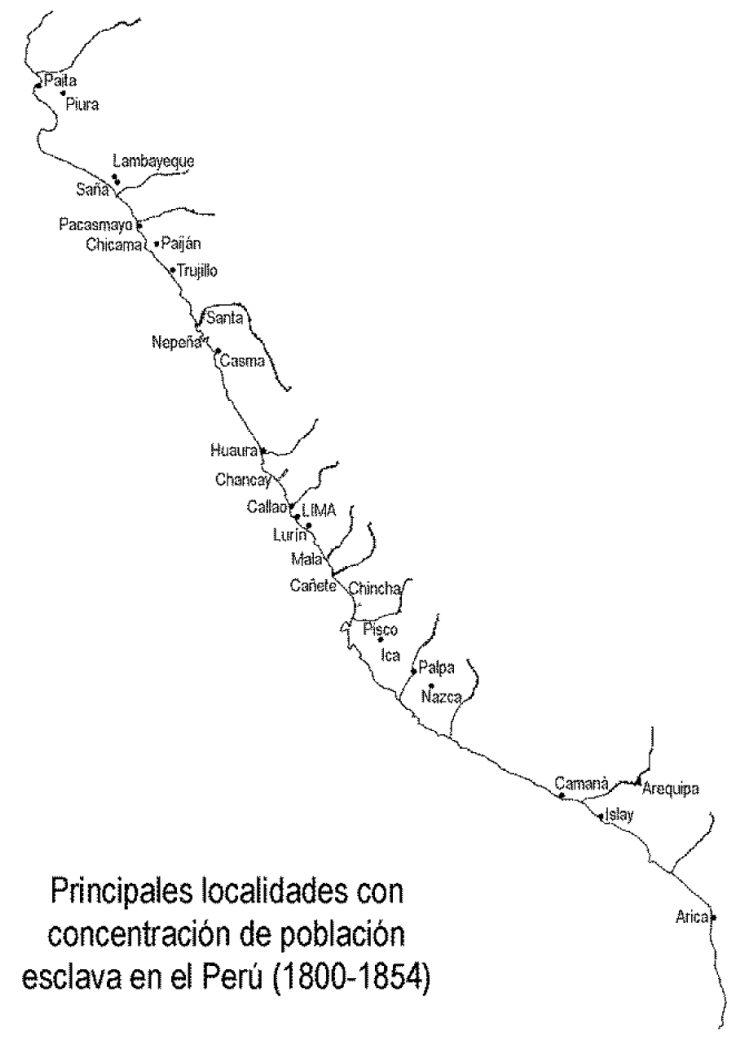

En cambio en la de Trujillo (que incluía los actuales departamentos de Tumbes, Piura, Lambayeque y Cajamarca), los 4725 esclavos que tenía en sus valles solo representaban el 2 por cien de su población; la intendencia de Arequipa (que comprendía Arica) contaba con 5258 esclavos que representaban casi el 4 por cien de la población. En las demás intendencias la población esclava llegaba a 591 personas y por tanto era un porcentaje insignificante. A partir de estas cifras podemos concluir que el «núcleo duro» de la esclavitud se encontraba en el Perú central, y básicamente en el área litoral dominada por Lima.

Es importante también considerar a la población «libre de color», que eran personas de origen esclavo que habían conseguido su libertad por medio de la manumisión o por ser producto de una "mixtura» racial, en que uno de los padres era libre. En el área limeña estas personas representan un 11,9 por cien de la población total, pero la población esclava la supera claramente con un 20 por cien sobre el total. En cambio en la intendencia de Trujillo, los libres de color llegan a representar el 6 por cien de la población total y triplican el número de esclavos. Algo análogo 
CuAdro 1: Población esclava y «libre de color» del virreinato peruano en 1792

\begin{tabular}{|l|c|c|c|c|c|}
\hline \multicolumn{1}{|c|}{ Intendencia } & Esclavos & Libres de color & $\begin{array}{c}\text { Resto de } \\
\text { población }\end{array}$ & $\begin{array}{c}\text { Total de } \\
\text { población }\end{array}$ & $\begin{array}{c}\text { Porcentaje de esclavos } \\
\text { sobre el total }\end{array}$ \\
\hline Lima & 29763 & 17864 & 101485 & 149112 & 20,00 \\
\hline Trujillo & 4725 & 13757 & 212485 & 230967 & 2,00 \\
\hline Arequipa & 5258 & 7003 & 123914 & 136175 & 3,86 \\
\hline Demás intendencias & 591 & 2780 & 556497 & 559868 & 0,00 \\
\hline Total & 40337 & 41404 & 994381 & 1076122 & 3,75 \\
\hline
\end{tabular}

* Incluye a españoles, mestizos e indios

** Comprende las intendencias de Tarma, Huamanga, Huancavelica y Cuzco.

Fuente: Vollmer, 1967.

ocurre en la intendencia de Arequipa donde llegan al 5,1 por cien y superan el porcentaje de esclavos. Sin embargo, en todo el virreinato los libres de color representan el 2 por cien frente al 3,75 por cien constituido por esclavos. Este resultado hace patente que el número de esclavos de la intendencia de Lima fue determinante a escala peruana.

Una observación más específica permite destacar que la ciudad de Lima era un núcleo de concentración de esclavos. Había allí 13497 esclavos, a los que se pueden sumar los 4402 que vivían en el suburbio adyacente del Cercado, es decir, había un total de 17899 esclavos urbanos que representaban un 60 por cien del total de la intendencia. En cambio en los campos de la intendencia de Lima había 11882 esclavos (en Cañete, Chancay, Ica y Santa básicamente).

Ya en vísperas de la independencia, el número de esclavos había disminuido significativamente en Lima y todo el Perú, resultado de la suspensión de la trata promovida por Gran Bretańa. En el cuadro 2 apreciamos que en la ciudad de Lima el porcentaje de esclavos sobre la población total pasó del 25 por cien al 10 por ciento.

El grueso de esclavos no se ubicaba en las áreas rurales, sino en la ciudad, así en 1836, como apreciamos en el cuadro el 63 por cien de esclavos era urbano (Aguirre 1993: 53). Procesos análogos se evidencian en otras regiones del Perú. Vemos que en la provincia de Trujillo que comprendía la ciudad y sus valles, la población esclava llegaba a cotas significativas en 1760: en la propia ciudad representaba el 39 por cien del total, mientras que en toda la provincia los esclavos representaban 36 por cien de los habitantes. La población de negros libres era prácticamente insignificante en esta fecha. Esta situación cambió radicalmente a raíz de la crisis de la agricultura trujillana (Lavallé 1998).

En efecto, en la segunda mitad del siglo xvinI, la ciudad de Trujillo y su región experimentó un cambio económico como resultado de una serie de catástrofes naturales, y la ruina de la producción de trigo que fue sustituida cada vez más por el cultivo de la caña de azúcar. Esto implicó un cambio demográfico notorio. Ya en 1784, la población esclava de Trujillo y sus valles se vio reducida a 1000 efectivos, mientras la población negra libre que había sido insignificante parece haber llegado a superar a los esclavizados. Es un proceso que se conoce poco, pero resulta patente a partir de las cifras que citamos. Paralelamente la población en general experimentó un crecimiento limitado por las circunstancias de ruina económica.

Cuadro 2: Población esclava en la ciudad de Lima, 1792-1845

\begin{tabular}{|c|c|c|c|c|c|}
\hline Año & Esclavos & Esclavas & Total de esclavos & Total de habitantes & $\begin{array}{c}\text { Porcentaje de } \\
\text { esclavos }\end{array}$ \\
\hline 1792 & 6414 & 7069 & 13483 & 52627 & 25,6 \\
\hline 1813 & 6400 & 5863 & 12263 & 56284 & 21,8 \\
\hline 1818 & 4705 & 3884 & 8589 & 54098 & 15,9 \\
\hline 1836 & 2185 & 3606 & 5791 & 55627 & 10,4 \\
\hline 1839 & Sin datos & Sin datos & 7922 & 65116 & 12,1 \\
\hline
\end{tabular}

Fuente: Aguirre, 1990: 137-178. 
Cuadro 3: Población según estatus en la ciudad de Trujillo y valles aledaños, 1760

\begin{tabular}{|l|c|c|c|c|c|c|}
\hline & $\begin{array}{c}\text { Negros } \\
\text { esclavos }\end{array}$ & Negros libres & Indios & Mestizos & Blancos & Total \\
\hline Ciudad & 3650 & 0 & 289 & 2300 & 3050 & 9289 \\
\hline Valle Chicama & 1134 & 32 & 1002 & 446 & 0 & 2614 \\
\hline Valle de Chimo & 291 & 0 & 1136 & 217 & 0 & 1644 \\
\hline Valle Virú y Chao & 102 & 21 & 509 & 104 & 0 & 736 \\
\hline Total & 5177 & 53 & 2936 & 3067 & 3050 & 14283 \\
\hline
\end{tabular}

Fuente: Centurión, 1954.

En 1792 toda la intendencia de Trujillo los negros libres casi triplicaban a los esclavos (13 757 frente a 4725). Dentro de dicha intendencia, la entonces provincia de Piura tenía un contingente más importante de negros libres, seguida por Lambayeque y finalmente la ya referida provincia de Trujillo. En la ciudad de Lambayeque en 1853 la población esclava era solo un 7 por cien en la ciudad. En cambio, los llamados morenos y pardos, muchos de los cuales tenían origen esclavo, representaron respectivamente un 4 por cien y un 15 por cien del total de la población de dicha ciudad (Pareja 2015: 203).

De esta síntesis resulta evidente una diferencia regional interesante: en el norte la población libre de origen africano (pardos, morenos) era numéricamente importante, mientras que en Lima su nivel demográfico era más reducido, y la mayoría de población de este origen estaban sujetos a la esclavitud. Por tanto, si bien el «núcleo duro» del sistema esclavista se encontraba en la costa central dominada por Lima, en términos generales la población afectada por el sistema esclavista tendía a disminuir debido al bloqueo de la trata. Esto lleva a plantear que la esclavitud era un sistema en decadencia y disolución, y que esto era patente sobre todo en la costa norte peruana.

\section{Los esclavos en la producción agrícola y en la economía urbana}

Existieron dos grandes grupos en la población esclava: los esclavos rurales, dedicados a trabajos agrícolas en las haciendas y chacras; y los esclavos urbanos, ubicados en la ciudad, y ocupados en el servicio doméstico, el pequeño comercio y las labores artesanales. Un grupo más bien reducido de esclavos trabajó en la economía extractiva representada básicamente por la actividad minera, en la que antes bien predominó el trabajo de los indígenas.

La mayoría de esclavos rurales trabajaban en las labores agrícolas de numerosas haciendas de la costa. Sobre todo en las de caña de azúcar, las chacras de panllevar y los viñedos. La jornada duraba doce horas. Vivían en un conjunto habitacional llamado "galpón», cuya mejor descripción quizá es la que procura Juan de Arona, pseudónimo de Pedro Paz Soldán, él mismo propietario por matrimonio de la hacienda «Matarratones»:

El conjunto de casas de quincha en donde vivían los negros esclavos de las haciendas, y en donde siguen viviendo hoy, libertos, junto con sus familias y demás peones.

Este conjunto de casas solía tener una plaza central perfectamente regular, de la que partían cuatro calles rectas más o menos largas, según la esclavatura de la hacienda, y componiendo un verdadero pueblecito.

Otros estaban cercados por altas paredes, que remataban en una gran portada de elegante fachada. (Arona, 1884: 234)

La idea del galpón era concentrar a los esclavos e impedirles el movimiento no controlado por sus dueños. A partir de los trastornos de la guerra de la independencia, la disciplina de este espacio se distendió, pues los amos perdieron el control sobre la circulación de hombres libres y esclavos fugados (cimarrones) en sus haciendas, lo cual dio pie a conflictos que dificultaron las labores agrícolas (Aguirre, 1993: 120-125).

Con frecuencia, los amos asignaban a los esclavos pequeñas parcelas donde podían cultivar hortalizas y verduras, criar animales, para complementar su dieta. Podían en un nivel reducido comercializar estos productos y obtener con ello algunos medios de 
ahorro para necesidades diversas y quizá para reunir los fondos con que liberarse mediante el pago de la manumisión (Hunefeldt 1992).

No existen estudios históricos ni arqueológicos sobre la cultura material de la vivienda de los esclavos, además carecemos de representaciones visuales de galpones en la etapa colonial o en la republicana. Para inicios de la república, apenas disponemos de un boceto realizado por el viajero inglés Clemens Markham que nos muestra un trapiche de caña de azúcar en que aparecen siluetas de trabajadores que presuponemos podrían haber sido esclavos (Markham 1991: 29 y 32).

En las ciudades en general la esclavitud doméstica tuvo una presencia importante. Realizaban todas las tareas del hogar y se encargaban de todas las necesidades de sus amos. Desde este punto de vista resulta particularmente expresiva la acuarela de fines del siglo XVIII en que se ve a un esclavo dedicado a extraer "piques» (un tipo de pulga) de los pies de su amo. Es una escena colonial que la república no alteró en lo fundamental. Empero, dentro de la situación subordinada de los esclavos había gradaciones y prestigios que los distinguían y podían causar disputas. Por ejemplo, en el oficio de calesero, un esclavo podía ostentar libreas y ropas de calidad por cuanto su aspecto reflejaba el estatus y la riqueza de sus amos. En el campo, los caporales esclavos tenían potestad para castigar físicamente a los esclavos sujetos a su mando.

Con todo, la llamada «esclavitud a jornal» fue el sistema que llegó a un mayor desarrollo en el medio urbano a fines de la etapa colonial y continuó siendo importante durante la república, sobre todo porque la destrucción causada por la guerra y la secuela de conflictos entre caudillos solo dejó a los esclavos como único recurso para obtener ingresos propios a muchos propietarios rurales y urbanos: eran su capital. Según este sistema, los esclavos podían ejercer diversos oficios y eran alquilados por sus amos y estos recibían el jornal correspondiente fuera en su totalidad o parcialmente. Los oficios principales para los esclavos eran los de aguador y peones para las chacras aledañas a la ciudad; las mujeres se desempeńaban como vendedoras callejeras, cocineras, lavanderas y amas de leche (Aguirre, 1993: 137-149). Aunque sus amos tenían derecho a quedarse con sus jornales, muchas veces este trabajo permitió a los esclavos retener parte de sus ingresos con el fin de poder elevar su nivel de vida y/o, sobre todo, comprar su propia libertad o la de sus seres queridos, es decir, lograr la manumisión (Hünefeldt 2002).

Aquellos esclavos que lograban la manumisión, fuera esta "graciosa» (por gracia de su amo) o comprada, y por tanto lograban convertirse en personas «libres de color» no tenían asegurado el poder ocupar oficios mejores que los de un esclavo a jornal, puesto que "La conquista de la libertad no iba acompañada por la posibilidad de formas sociales y laborales distintas de las que habían tenido cuando eran esclavos» (Aguirre 1993: 166). Algunos investigadores plantean, no obstante, que es necesario examinar el significado de la libertad para los propios esclavos (Mejías 2007).

La esclavitud quedó inscrita en la división de oficios dignos e indignos, asociando estos últimos con la condición servil o esclava y a un determinado color de piel. Esto afectó necesariamente a las personas «libres de color», a los que conjuntamente con los esclavos se les suele llamar "sociedad negra», "afrodescendientes», «afroperuanos», aunque aquellos que no estaban sometidos a la esclavitud. Un ejemplo de ese impacto se apreció en el ejercicio de la medicina, pues muchos profesionales eran «libres de color» por lo que esa profesión arrastraba un cierto lastre de inferioridad frente a los clérigos y abogados (Jouve, 2014: XIV-XV).

\section{La coyuntura de la independencia: guerra y ¿libertad?}

En el fragor de la guerra tanto los realistas como los patriotas se vieron obligados a movilizar a los esclavos con la promesa de la libertad para poder contar con tropas de choque. Esta oferta se dirigía obviamente a los varones esclavos. Por ejemplo, el virrey José de la Serna prometió la libertad a 500 esclavos que lucharan por el rey (BNP 18 de febrero de 1821). Los jefes patriotas admitían que la esclavitud era una institución contraria a los derechos del «hombre y el ciudadano", pero pensaban que no era urgente destruirla de inmediato. Sin embargo, la presión por obtener personal para el ejército dando alguna motivación a los esclavos para sumarse a las fuerzas patriotas y, probablemente, los ideales liberales de Bernardo Monteagudo llevaron a José de San Martín a dar el 
decreto del 12 de agosto de 1821 que otorgaba la libertad a los niños nacidos de esclavas desde el 28 de julio de 1821. Fue la llamada ley de la «libertad de vientres», que se publicó originalmente en la Gaceta del gobierno de Lima Independiente el 18 de agosto de 1821. Cabe precisar que este decreto quedó limitado por el de 24 de noviembre de 1821 que obligaba a estos hijos de esclavas a permanecer con sus amos hasta los 25 ańos (los hombres) y 18 ańos (las mujeres), es decir, los hacía libertos, no personas libres.

Algunos amos — por exhortación de los jefes patriotas - entregaron sus esclavos al Estado para que dispusieran de ellos en sus ejércitos, con lo que el estado republicano quedaba en la posición de ser propietario esclavista. De este modo el estado republicano en ciernes dejó claro que reconocía la esclavitud como generadora de una propiedad legítima. El siguiente documento reconoce que la república ha «rescatado», es decir, comprado, un esclavo llamado José Zapata, a su propietario José Porras por 300 pesos, para servicio del propio estado, lo que generalmente significaba servir en el ejército.

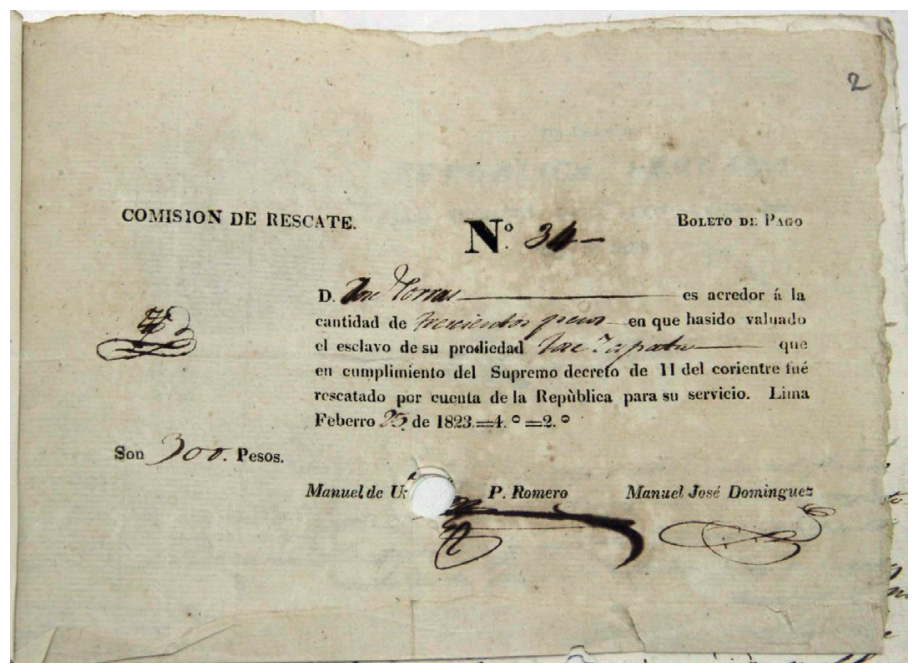

FIGURA 1. Boleto de pago emitido por el Estado por el esclavo José Zapata (Fuente: AGN, OL 164-1248).

Hipólito Unanue, que fue asesor de virreyes y ministro de Hacienda de San Martín y Bolívar, cedió a la esclava Juana Crisóstomo de su hacienda «Matarratones» (San Pedro de Arona en Cañete) al estado para que dispusiera de ella según sus necesidades (AGN, OL 52-47). Es decir, muchos amos expresaron su patriotismo y su deseo de libertad justamente cediendo sus esclavos al estado, el cual debía ser su nuevo amo. No veían ninguna contradicción en esto, pues la idea de libertad no comprendía la idea de igualdad entre las personas. Y con esto reafirmaban el principio de que los esclavos no eran sino cosas de su propiedad.

\section{El estado republicano y la esclavitud: leyes y propiedad}

Lo anterior hace patente que el estado republicano naciente tuvo un carácter esclavista, contrario a los principios que teóricamente le daban sustento moral frente al colonialismo hispánico. Además de adquirir esclavos, el estado se convirtió en propietario de los esclavos de las haciendas que habían pasado a su administración como resultado de las expropiaciones de la guerra por la independencia y como heredero de propiedades agrarias que habían estado en poder del estado colonial. El caso de las haciendas de San Javier y San José de Nasca ilustra bien este aspecto poco conocido. En 1826 el Estado ordenó un inventario de la "esclavatura" (el conjunto de esclavos) en la hacienda de San José de Nasca: se enumeran dos esclavos que eran los caporales, 16 esclavos casados, 28 solteros, los párvulos o nińos eran 39, las niñas 20 (cuatro de pecho, es decir candidatos a la libertad por haber nacido después del 28 de julio de 1821, había 42 solteras. No se sabía con seguridad cuántos esclavos había habido antes de 1824, año en que la hacienda dejó de tener un administrador que diera cuenta de la gestión. El de ese entonces había dejado la hacienda llevándose 7 esclavos y 10 esclavas, todos bastante jóvenes: la mayor de las esclavas tenía 35 años (AGN, PL-7 229c).

Los acreedores del estado contaban con el estado como propietario de esclavos que garantizaban los préstamos que le habían otorgado. Así, en 1826, Isidro Aramburu, un comerciante al que el estado le debía más de 39 mil pesos (la unidad monetaria de la época), propuso al Estado que le alquilara 10 esclavos de los 300 que creía que había. A esta propuesta respondió el representante del Estado que solo había cinco esclavas: todas estas mujeres eran muy jóvenes: de 2 a 25 años de edad; el resto había escapado, o muerto; y había una familia de tres que habían ido a Lima para gestionar su libertad (AGN, OL 6-311). Es decir, no era un rechazo al principio de propiedad 
sobre seres humanos lo que impulsaba al representante del Estado a no aceptar la propuesta de Aramburu, sino la dificultad de hacer realidad dicho principio. Además el Estado republicano siguió reglamentando la esclavitud y legislando de manera que los avances de un proyecto de abolición gradual de la esclavitud fueran quedando muy relativizados, como veremos a continuación.

\section{6. ¿Quiénes procuraron el mantenimiento de la esclavitud?}

El decreto de San Martín fue tomado por los terratenientes y los dueños de esclavos en la ciudad y en el campo como una medida que solo respondía a la emergencia de la guerra. Se resistían a considerar que sus esclavos podían ser personas con voluntad propia y autonomía. El principio del respeto a la propiedad privada, que fue apoyado por la revolución independentista sirvió para defender legalmente el control de los amos sobre los esclavos.

De todas maneras, ya en el contexto cultural y político que inauguró la república era casi de mal gusto defender la esclavitud sin más, pues la revolución de la independencia se había realizado teóricamente para garantizar la libertad, establecer la igualdad y lograr la fraternidad. José María Pando (1787-1840) que fue ministro de Hacienda y de Relaciones Exteriores de varios gobiernos entre 1825 y 1834 , se encargó de defender a los esclavistas limeños para lo que publicó un folleto llamado Reclamación de los vulnerados derechos de los hacendados en 1833 que aceptaba retóricamente que la propiedad de esclavos era "propiedad triste, repugnante, abominable», pero aun así debía ser respetada porque era propiedad privada, el principio básico de la sociedad. Con ello justificaba las exigencias de los hacendados de la costa central, Lima, Cañete y Chancay contra lo que llamaban una «emancipación prematura» (Pando 1833: 7 y 10). Describió Pando una imagen funesta de los «libertos», es decir aquellos hijos de esclavas que por edad iban a ser definitivamente libres al cumplir 18 años en 1839 al beneficiarse de la llamada libertad de vientres decretada por José de San Martín el 18 de agosto de 1821, los veía como una generación totalmente peligrosa y amenazante para la sociedad. Según Pando era de temer el aumento de la criminalidad. Le escandalizaba prever que en un futuro no muy lejano los libertos gozarían de los mismos derechos que el resto de los ciudadanos peruanos (Pando 1833: 24 y 44-45).

El Reglamento de Policía para la Capital de la República de 1839 comprendía una serie de artículos relativos a los esclavos y al trato que deberían recibir. En este cuerpo legal se establecía la pena de azotes para esclavos prófugos, también señalaba que los esclavos debían portar un «boleto» o cédula de identidad en que se indicaba su identidad e iba firmado por el amo y el teniente de policía de la localidad. Si un esclavo no disponía de ese boleto, se le impondría castigo de azotes, el trabajador libre en cambio si carecía de dicho boleto, sería penado con multa o días de arresto (Tardieu 2005: 306-309).

Los hacendados apoyaron la ley de 24 de diciembre 1839 que en la práctica desconocía el decreto de libertad de vientres pues tras señalar que los libertos al cumplir la edad estipulada para dejar de estar bajo sus amos llevaban una «vida vaga», que su libertad «súbita» los predisponía a desórdenes que atentarían contra la moralidad pública, decretaba que los «hijos de esclavos declarados libres por el decreto de 12 de agosto de 1821» debían quedar bajo el patronazgo de sus amos hasta los 50 años, y que nadie podía impedir que siguieran sirviendo durante estos ańos, es decir solo serían libres hacia 1854 . El patronazgo podía ser cedido por los patronos, es decir, prácticamente reinstauraba la trata (Tardieu 2005: 309311). Por eso los sectores favorables a la esclavitud no proponían una paulatina libertad sino una paulatina restauración de la esclavitud, jugando con distintas denominaciones y precisiones legales.

La visión idílica de la esclavitud fue propagada como posición oficial por José Gregorio Paz Soldán, ministro de Relaciones Exteriores, en su «Memoria sobre la esclavatura en el Perú» de 1846, en donde fustigaba a los abogados que procuraban obtener la libertad de los esclavos (Aranda 1890-1911, 8: 206208). Desde su punto de vista, prácticamente eran los dueños de esclavos las auténticas víctimas de tramas legales que en realidad tampoco beneficiaban a los esclavos. Paz Soldán se refería los vínculos afectivos entre esclavos y amos como excusa para la falta de libertad de aquellos.

Paz Soldán buscó argumentos para reducir a la nada los decretos de 12 de agosto de 1821 y 24 de noviembre de 1821 dados por José de San Martín 
"caudillo de un ejército extranjero auxiliar» que no tenía «ninguna misión legislativa». Esos decretos debían ser considerados solo "máquinas de guerra», contra el poder español, pero para disgusto de Paz Soldán, los constituyentes peruanos los refundieron en el art. 152 de la constitución de 1823. Considera que mientras para los demás países hispanoamericanos que casi no tenían esclavos, las medidas que limitaban la esclavitud no tenían mayor importancia, pero para «nosotros» era un «sacrificio» positivo. Notemos que el «nosotros» de Paz Soldán alude a los peruanos, pero entre ellos no están incluidos los esclavos nacidos en el país.

Concluye Paz Soldán que es un gran beneficio que la constitución de Huancayo (1839) haya dado a «todo peruano» el derecho de importar esclavos al territorio, y que era un acto de soberanía permitir el tráfico interamericano de esclavos. Así en su opinión se salvaría la agricultura (de los hacendados). El concepto de «peruano» en Paz Soldán solo tiene validez para el limitado número de personas que eran más o menos sus pares sociales. Por parentesco, Paz Soldán sabía qué intereses estaba defendiendo ya que su hermano era un importante propietario esclavista por su matrimonio con la heredera de la hacienda «Matarratones», situada en Cañete (Blanchard 1992: 201).

\section{7. ¿Quiénes buscaron la abolición de la esclavitud?}

Algunos liberales peruanos propusieron una abolición gradual. Sus motivos iban desde lo económico hasta lo sociocultural. Al igual que muchos hacendados esclavistas pensaban que la libertad de los esclavos perjudicaría la agricultura, ya castigada por la guerra independentista. Otros se alarmaban con la idea del desorden social. Parte de su inconsecuencia estaba motivada por su dependencia de la hacienda como institución económica y social. Por ejemplo, Domingo Elías, rival y aliado de Ramón Castilla, según las coyunturas, era un importante hacendado que tenía esclavos en Ica y a su vez fue promotor de las ideas liberales y fundador del Colegio de Guadalupe, centro de agitación liberal.

Los estudiosos coinciden en que la prensa y otros medios escritos adoptaron una postura convencionalmente antiesclavista, pero sus prácticas no abonaban esta lucha (Blanchard 1992: 190-191). Por ejemplo,
El Mercurio Peruano era impreso por la Imprenta de la Libertad, pero no tenía reparos en incurrir en la paradoja de publicar avisos de venta de esclavos. El Comercio en sucesivos editoriales cuestionó el sistema esclavista, pero en sus páginas podían encontrarse avisos anunciando la venta de esclavos de ambos sexos y denuncias por fuga de esclavos.

Sin embargo, especialmente en la profesión jurídica hubo personas que aprovecharon todos los aspectos legales que podían favorecer a los esclavos en el logro de la libertad. Así los llamados «defensores de menores» tuvieron una actividad muy decidida en este sentido, por lo que se les puede considerar verdaderos abolicionistas (Aguirre 1990: 209), con lo cual se ganaron la enemistad de hacendados y poderosos estadistas como Pando o Paz Soldán. En este sentido merecería una mayor atención por parte de los historiadores una persona como Manuel José Bravo de Rueda que desempeñó este cargo de manera continua entre 1830 y 1840 aproximadamente ante la Corte Superior de Justicia de Lima (Paredes 1832: 46; 1833: 47; 1836: 47; 1837: 38; Carrasco 1840: 74).

En ciudades como Trujillo y Piura dicho cargo lo ejerció el síndico de los municipios. Así hallamos en 1832 en Paita al síndico Francisco Távara, asumiendo la defensa de los derechos de una pareja de esclavos neogranadinos que habían sido vendidos en Tumbes por un hacendado de Loja (AGN, RPJ, Causas Civiles, caja 65, expd. 1072). Resulta interesante anotar que este defensor era hermano del célebre liberal Santiago Távara que publicaría en 1855 su texto Abolición de la esclavitud en el Perú. En Lambayeque actuó el regidor José Matías Costa como defensor. En un caso debió hacer cumplir el decreto que otorgaba la libertad a todo esclavo que pisara suelo peruano (ARL, leg. 2 , $\mathrm{f}$. 67-68, Escribano José Matías Delgado, escritura 43, 24 de marzo de 1823).

El conocimiento de las iniciativas abolicionistas es parco. Hay noticias del intento de Manuel Tafur en Tumbes que, en enero de 1853, dirigió un movimiento contra Echenique, y proclamó: «son libres los esclavos, sean felices los descendientes de Manco». Sin embargo, parece haber fracasado (Sus amigos, "Al Sr. D. Manuel Tafur», El Comercio, 13 de enero de 1855; Juan Crisóstomo Doblado, «D. Manuel Tafur como candidato a la Convención", El Comercio, 21 de abril de 1855, p. 3). 


\section{La esclavitud en la esfera pública republicana: los esclavos en la prensa}

Aunque la república se constituyó con un discurso sobre la dignidad universal de los seres humanos, en realidad se mantuvo en suspenso la construcción de una institucionalidad y el ejercicio de prácticas que permitieran alterar radicalmente la configuración mental anclada en el régimen estamental propio de la etapa virreinal. Antes bien se la recreó con nuevos ingredientes, proceso al que no fue ajeno el estado de violencia evidente o latente que ha recorrido la historia republicana.

Una institución que se considera elemento esencial de la constitución de la llamada esfera pública de la sociedad civil es la prensa periódica. Esta fue introducida con cortapisas en las últimas décadas de la era colonial. Con la proclamación de la república alcanzó una mayor difusión y capacidad expresiva, aunque pronto se hizo sentir la censura. Si bien el destinatario ideal de esta prensa era el sector letrado, predominantemente masculino y de estatus superior, esta vía de comunicación letrada que no se limitaba al que supiera leer (escribir podía ser un aprendizaje separado), sino que mediante la lectura en voz alta llegaba también a los iletrados.

En los años inmediatos a la proclamación de la independencia la esclavitud no fue un tema abordado de manera abundante en dicha prensa, exceptuando las disposiciones legales que atañían a los esclavos. Por tanto podemos decir que la emergente sociedad civil no lidió con el problema de forma abierta. Existe sin embargo una forma menos evidente y que naturalizó la esclavitud como ingrediente constitutivo de la cotidianidad social mediante la expresión escrita: los avisos de compra-venta de esclavos en la prensa diaria. En ellos se describe sucintamente el bien que se oferta o se demanda: el esclavo o la esclava. Esta descripción sucinta no obvia denominaciones raciales que después servirán para la plena instauración del racismo bajo el manto liberal de la república.

El Mercurio Peruano fue un diario fundado por José María Pando, líder intelectual del sector esclavista limeño y peruano en general. En agosto de 1827, mes de la aparición de este diario la república tenía ya seis años de vida, y los nacidos libres de madre esclava estaban por alcanzar la misma edad, pues el decreto de libertad de vientres se proclamó el 2 de noviembre de 1821. Pero un aviso de dicho diario nos hace ver que la operatividad de la esclavitud jugaba en el filo de la legalidad republicana.

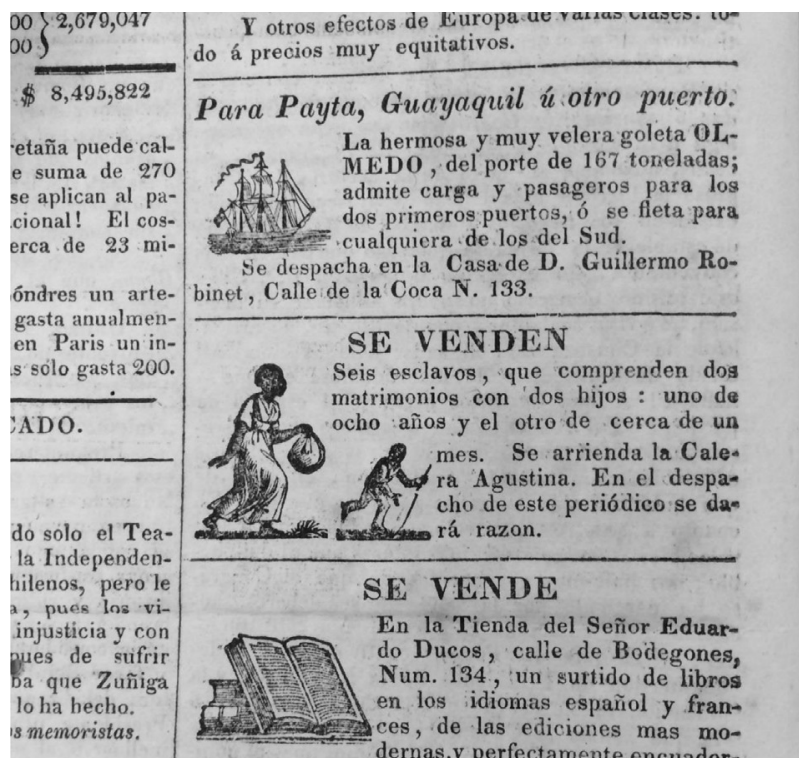

FIGURA 2. Aviso que ofrece en venta dos familias esclavas. Fuente: Mercurio Peruano, 2 de agosto de 1827, p. 4.

Aquí leemos que se ofrecen seis esclavos que forman dos familias. Uno de los niños tiene 8 años, por tanto es exacto llamarlo esclavo, pues habría nacido en 1820, pero el de casi de un mes de nacido, no podía ser llamado así, ya que nació evidentemente en 1827 , por tanto era libre por el decreto de «libertad de vientres» de 1821. Alguien debe de haber hecho alguna observación al respecto porque días después, el 29 de agosto de 1827, se vuelve a publicar el aviso, pero sin ninguna indicación de edades ni parentesco. De manera que no podía evidenciarse que el vendedor estuviese incurriendo en una violación de la ley al vender como esclavo a una persona libre.

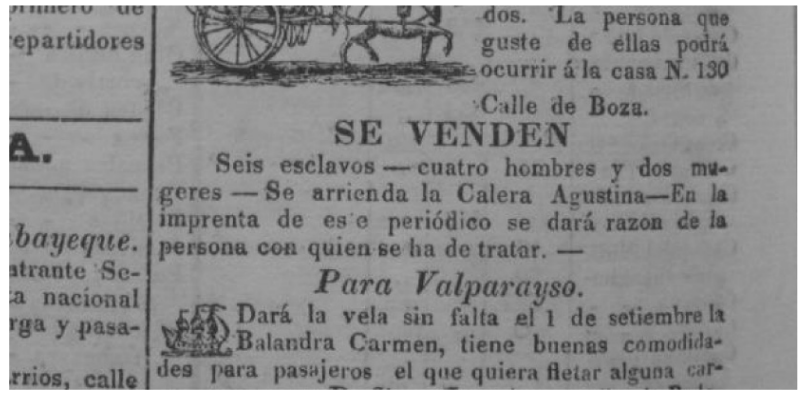

FIGURA 3. Aviso en que se ofrece en venta seis esclavos sin indicar sus relaciones mutuas. Fuente: Mercurio Peruano, 29 de agosto de 1827, p. 4. 
Este medio impreso, que se identificaba orgullosamente con los valores republicanos, no tenía reparos en publicar avisos de trata esclavista. Así se anuncia que quien quiera vender a un niño esclavo (de 10 a 12 ańos) debe acudir a la imprenta que se autotitula «de la LIBERTAD» (!). Cabe apuntar que en mayo de 1828, quizá en aras de la coherencia, dicho diario se limitó a consignar en el pie de imprenta solo con el nombre de su propietario: J. Masías.

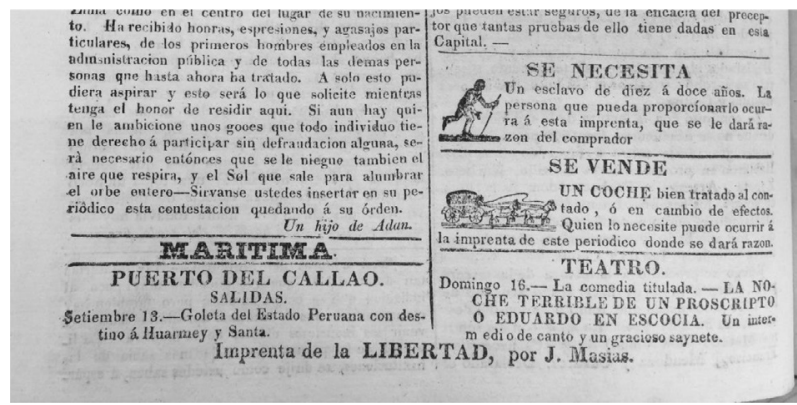

FIgURA 4. Aviso de demanda de un niño esclavo y pie de imprenta del Mercurio Peruano. Fuente: Mercurio Peruano, 15 de setiembre de 1827, p. 4.

Probablemente la inclusión de litografías con imágenes de esclavos o esclavas dependía de lo que el anunciante quería pagar. A su vez sugiere la creación de un estereotipo. Con los medios técnicos al alcance la fijación en la piel negra del esclavo no dejaba lugar a matices. La mujer lleva un atado y el hombre además una especie de cayado, y con actitud de caminar hacia algún lugar. Esta representación de la errancia y la desposesión era la que los habitantes de la ciudad podían asociar con sus prójimos esclavos, antes que las imágenes más vívidas de acuarelas y pinturas costumbristas. Sin embargo, estas litografías no aparecieron con mucha frecuencia en la prensa limeña, probablemente por limitaciones económicas de los anunciantes.

Los últimos esclavos bozales, es decir, aquellos nacidos en África en contraste con los «criollos» nacidos en el Perú, pueden ser los que aparecen en venta en este diario el 7 de febrero de 1828. Recordemos que la trata quedó suspendida ya en 1817 hacia el Perú, pero la presión por reabrirla por parte de los hacendados no cesó. Por otra parte, se sabe que en la Lima de 1860, ya abolida la esclavitud, permanecieron unos 90 africanos cuyo origen se puede remontar a los últimos embarques de esclavos del siglo XIX
(Cosamalón 2014). El empleo de la misma imagen en la prensa para anunciar la venta o compra de esclavos de diferente raíz cultural unificaba al colectivo esclavo en la negritud, un estereotipo racial.

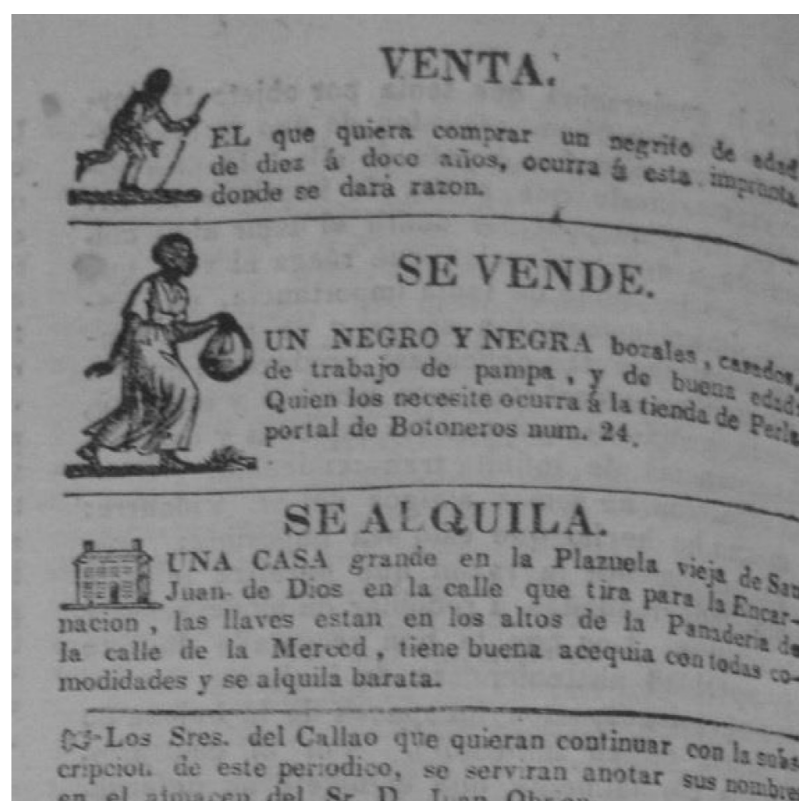

FIGURA 5. Aviso de venta de esclavo y esclava bozales.

Fuente: Mercurio Peruano, 7 de febrero de 1828, p. 4.

Al igual que libros, pianos, calesas y barcos, el esclavo es representado en cuanto es mercancía, y así impacta al público lector o al que simplemente sin necesidad de leer ve la imagen impresa. Desde ese punto de vista se puede argumentar que no necesariamente la prensa creó ciudadanos o espacios democráticos conducentes a un igualitarismo, según se argumenta desde la perspectiva de la «sociedad civil». Simplemente, esta prensa les confirmaba a los dueños de esclavos que estos eran objetos y por tanto cabían plenamente en la noción de propiedad privada, argumento que tendrá un papel estelar en la defensa de la esclavitud por parte de los hacendados representados sucesivamente, como hemos visto, por los estadistas Pando y Paz Soldán.

\section{La lucha de los esclavos por la libertad: manumisión y rebelión}

Fueron los propios esclavos quienes con más empeño buscaron el fin de la esclavitud. Para ello se valieron de las leyes existentes que permitían la manumisión, 
pero en muchos casos optaron por evadir el sistema mediante la fuga, y también hubo rebeliones esclavas en ciertas localidades.

La opción de la manumisión fue sobre todo accesible a los esclavos urbanos, menos para los esclavos rurales, aunque estos podían obtener ingresos extras a través de la venta de productos de sus pequeñas parcelas para subsistencia. También era posible, pero igualmente difícil, que el amo o ama les otorgara la libertad, sobre todo como su última voluntad. Esto lo lograba solo una minoría.

Para hacer asequible la manumisión, es decir, la autocompra, los esclavos procuraban que su valor fuera bajo. Incluso los esclavos que habían acabado perteneciendo al Estado como parte de las haciendas expropiadas, se vieron en el trance de pedir a sus funcionarios que rebajaran su valor para poder pagarlo. Así en 1827 Atanacia de la Cruz, esclava de la hacienda del estado de San José de Nasca, queriendo conseguir su libertad, pidió que se rebajara su valor en atención a estar enferma y haber tenido seis hijos que quedaban como esclavos de la hacienda (AGN, PL 7-193). Esa fue la lucha del esclavo de la mencionada hacienda que al ser tasado en 200 pesos dijo (por su procurador) que no se podía entender dicho precio por ser inválido (tullido de ambas piernas, con tumores, etc.) y pidió que un médico lo reconociera y diera constancia de su mal estado. En igual sentido se manifestó la esclava Margarita que había sido tasada en 250 pesos. En todos estos casos la elevada «apreciación» resultaba en desmedro de los intereses del esclavo que aspiraba a la libertad. En ciertas instancias de la administración, había funcionarios que podían tender a recomendar la rebaja del precio de autocompra, pero esto se oponía a la actuación de los tasadores que tendían a fijar precios elevados que causaban la protesta de los esclavos interesados (AGN, PL 7-229c). Apreciamos así que la sujeción esclavista producía un efecto reflejo en la propia persona del esclavo, la cual debía darse un valor monetario a sí misma que fuera lo más bajo posible para así poderlo cubrir con sus recursos. En contraste, de una forma bastante descarnada, los funcionarios de Hacienda no ahorraban esfuerzos por extraer el máximo valor de los esclavos en su poder. Así en 1828 la Dirección General de Consolidación negó a la madre de la joven esclava Isabel vendérsela a 125 pesos, aduciendo que esa tasación correspondía a esta cuando tenía once ańos, y que en este momento ya era mayor (AGN, PL-8 670). Por otra parte, Hacienda podía «arrendar» a los esclavos para que trabajasen para particulares. Este tipo de manejos hacía evidentes las incongruencias republicanas: en un oficio se dice que los esclavos se arrendaban "con calidad de pagar por cada individuo 8 pesos mensuales, alimentarlos y tratarlos como a hombres iguales» [subrayado M. C.], (AGN, PL-6 606).

Casos de manumisión notables por lo numerosos se dieron en el norte del país. Ya hemos señalado que la esclavitud como institución se encontraba en plena desintegración especialmente en esa área. Es posible que algunos liberales del norte hubieran debatido con más amplitud el problema de la extinción de la esclavitud, pero el sesgo centralista de la historiografía peruana y las limitaciones de las historiografías locales no permiten por ahora definir este tema. El hecho más notable es que en 1846 Hipólito Bracamonte, marqués de Herrera y Valle Hermoso, dictó un testamento en el cual concedió la libertad a unos 115 esclavos de su hacienda Chiclín, en el valle de Chicama. La condición era que permanecieran como trabajadores libres en esa propiedad, recibiendo jornal y alimento. Solo si eran maltratados o estuvieran impagos podrían separarse de la hacienda "previo conocimiento de la justicia, pero no habiendo motivo para la separación se les compelerá a que vuelvan a la hacienda» (Centurión 1954: 13). Es decir, eran libres pero de modo muy relativo, pues no podían dejar Chiclín para trabajar en una hacienda

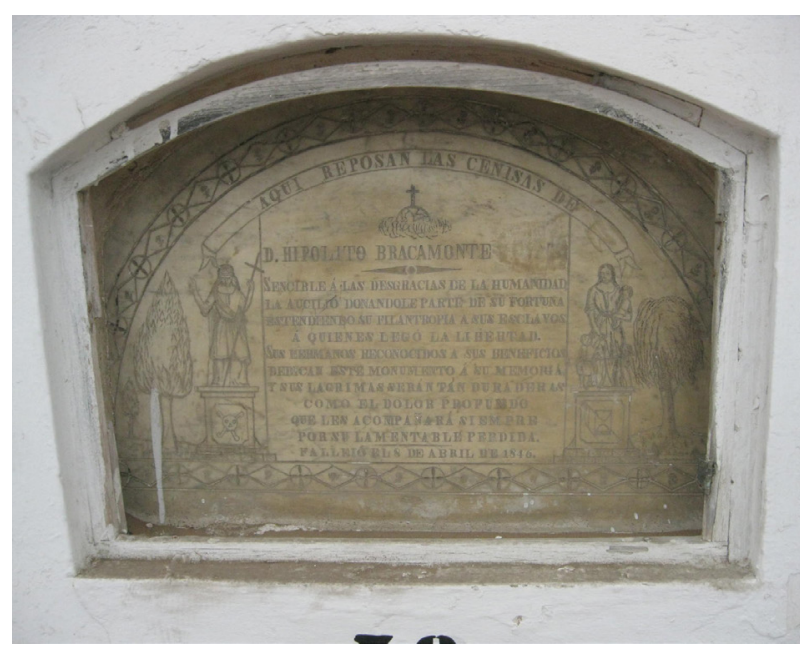

FIGURA 6. Lápida de D. Hipólito Bracamonte en el cementerio de Trujillo en que se indica que legó la libertad a sus esclavos (foto M. Chocano) 
que les ofreciera condiciones mejores sea monetarias o de otro tipo. Algunos vieron en esta decisión un ejemplo de "gran humanidad». Su epitafio en el nicho no 55 del cuartel San Juan Cancio, del cementerio de Trujillo, reza: «Aquí reposan las cenizas de D. Hipolito Bracamonte. Sensible a las desgracias de la humanidad la auxilió dándole parte de su fortuna extendiendo parte de su filantropía a sus esclavos a quienes legó la libertad. Sus hermanos reconocidos a sus beneficios dedican este monumento a su memoria y sus lágrimas serán tan duraderas como el dolor profundo que les acompañarán siempre por su lamentable pérdida. Falleció el 8 de abril de 1846» [ortografía actualizada, M. C.].

Lo cierto es que el marqués legaba una libertad muy limitada, que aseguraba a la hacienda de Chiclín contar con trabajadores en un contexto en que era muy difícil adquirir nuevos esclavos, y además invocaba al poder del Estado (es decir el uso de la fuerza pública) para mantener a estos exesclavos fijados a ese lugar. Resulta de interés que pese a estas presuntas ventajas, la agitación antiesclavista fuera más notoria en el norte que ningún otro lugar de la república, tal como se verá más adelante.

Fuera del recurso legal a la manumisión y de la opción radical de la rebelión, se abría la alternativa ilegal de la fuga. Así el esclavo rechazaba por completo el control del amo. Sin entrar en las motivaciones concretas de cada esclavo para tomar la decisión de fugarse, en la mayoría de casos era una forma de escapar al maltrato que experimentaban y/o el deseo de reunirse con sus seres queridos que por haber sido vendidos estaban lejos. Los amos trataban de recuperarlos para evitar la pérdida económica que significaba su ausencia. Para esto utilizaban los avisos en la prensa, en que solían dar descripciones detalladas de los esclavos huidos o "cimarrones", que eran ofrecidos en venta a precio rebajado porque había que correr con el costo de recapturarlos, tal como apreciamos seguidamente.

Sin embargo, antes que la fuga, la resistencia radical a la esclavitud la encarnaban las sublevaciones esclavas. Estas fueron pocas y de alcance local en el área limeña: hubo motines en 1826, 1833, 1844 en la hacienda San Pedro de Cañete (Aguirre 1993: 276284); hay una escueta noticia de una rebelión en las haciendas de la orden de la Buena Muerte en Cañete en marzo de 1851 («Cańete», El Comercio, 7 de marzo de 1851). En cambio, en la costa norte del Perú

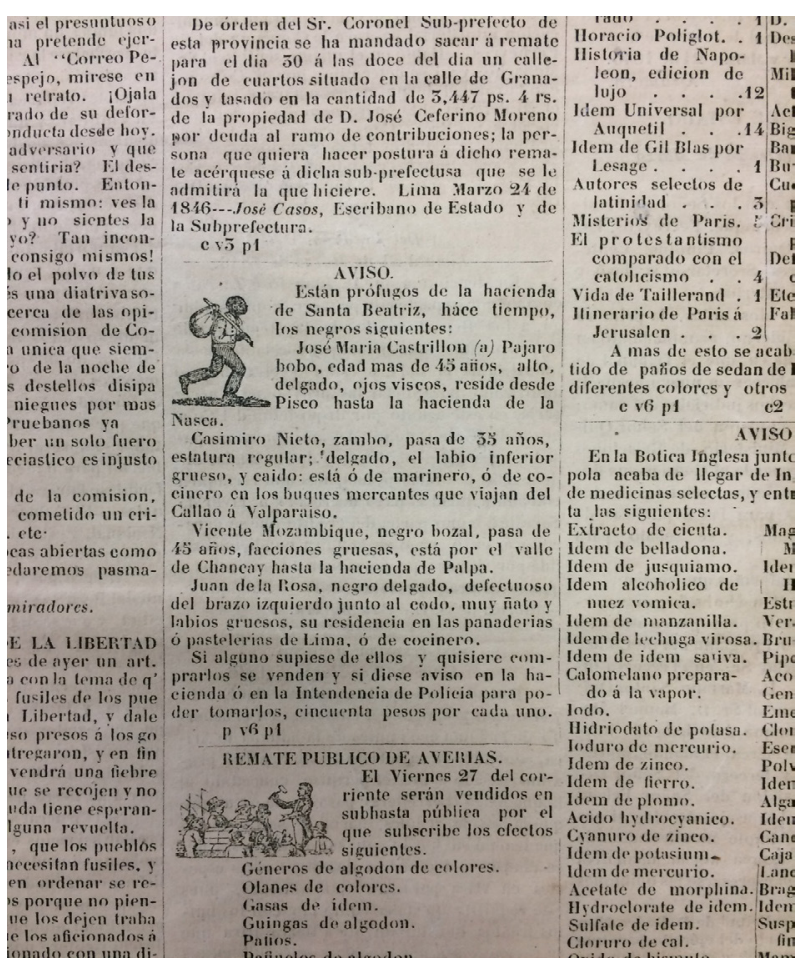

FIGURA 7. Aviso de búsqueda de esclavos prófugos.

Fuente: El Comercio, 26 de marzo de 1846, p. 4.

las noticias de la agitación esclava son más nítidas y desembocaron en la gran insurrección esclava de Trujillo en 1851, cuyo antecedente se puede leer en la rebelión de diciembre de 1850 , cuando veinte esclavos de la hacienda Chiquitoy atacaron al mayordomo y se apoderaron de sus armas. Estos esclavos fueron reprimidos y apresados, pero al año siguiente se produjo un levantamiento de mayor alcance. Asesorados por artesanos libres de color, los esclavos del valle de Chicama y los del de Santa Catalina, se organizaron demandando cartas de manumisión y una serie de reivindicaciones entre las que destaca el pedido de liberar a los presos de Chiquitoy. Los esclavos de los valles marcharon a Trujillo el 29 de enero de 1851, y en el camino sostuvieron enfrentamientos armados en Chocope. Al llegar a Trujillo se les unieron muchos esclavos urbanos. El resto de la población se mantuvo expectante. Los esclavos lograron la firma de sus cartas de libertad y celebraron el acontecimiento en la ciudad. Poco después llegaron las fuerzas del orden y sorprendieron a los sublevados. Los dirigentes fueron capturados y condenados. Se produjo una paradoja, mientras los esclavos rebeldes fueron rescatados de la cárcel mediante fianzas suscritas por sus amos que necesitaban su trabajo para sus haciendas y 
demás empresas, las personas libres implicados en la rebelión fueron condenados a penas de prisión, que no cumplieron por una ley de amnistía dada por el presidente Echenique (Dieguez Deza 2013). En el contexto de la costa norte, se puede sugerir que el peso demográfico de la población libre de color desempeñó un papel fundamental en el debilitamiento de la esclavitud. En cambio, en el área de influencia de Lima, el número de los libres de color era más reducido y su influencia política era limitada. Quizá esa sea en parte la explicación del porqué no ocurrieron rebeliones esclavas en dicho espacio.

\section{La abolición de la esclavitud: una oportunidad aprovechada en 1854}

En la historia oficial el protagonista de la abolición es el general Ramón Castilla. Sin embargo, fue un proceso mucho más complejo. En 1854 el país estaba sumido en una nueva guerra civil. Se enfrentaban el presidente Rufino Echenique y diversos caudillos. El proceso de la consolidación de la deuda había suscitado una gran disputa y se acusaba a Echenique de dirigir un régimen corrupto y represivo («los mashorqueros»). Los liberales, representados por diversos jefes como Domingo Elías, José Gálvez, Manuel Ureta, agitaron la bandera de la anticorrupción. Por esta razón la historiografía reconoce en este período el de la «revolución liberal». Los sectores contrarios a Echenique, necesitados de un ejército para combatirlo, encontraron en Ramón Castilla el caudillo experimentado para lanzarse a la guerra con probabilidades de éxito.

Echenique, viendo que no contaba con tropas suficientes, dio un decreto el 18 de noviembre de 1854 en que otorgaba la libertad a todo esclavo que se uniera a su ejército. Esto motivó a Castilla a hacer otro tanto con el decreto de 3 de diciembre de 1854 , firmado por Manuel Ureta en que se da la abolición. Por esto se puede decir con exactitud que dicha medida estuvo marcada por el oportunismo político de los jefes militares en lucha, antes que por los ideales abolicionistas (Blanchard 1992: 190-197).

La batalla decisiva entre ambos bandos ocurrió en enero en La Palma (Miraflores), pero el decreto no fue refrendado inmediatamente. Aprovechando las vacilaciones de Castilla los hacendados procuraron anular dicho decreto tratando de ganar la vo- luntad de este caudillo. Los partidarios de la abolición y los antiabolicionistas publicaron en la prensa diversos artículos defendiendo sus puntos de vista. Probablemente lo que inclinó la balanza a favor de refrendar el decreto fue la actividad de los partidarios de la abolición de publicar el bando del decreto en las calles de Lima, y aunque las autoridades hicieron quitar esos avisos, ya la noticia había corrido y «la ciudad y los campos presentaron el aspecto de una sublevación general» («Reforma», El Comercio, 26 de enero de 1855: 2-3). En ese contexto resultó difícil dar marcha atrás y anular el decreto, el cual se publicó el 25 de abril de 1855 y se comenzaron a dar pasos para el pago de la indemnización a los antiguos dueños.

El proceso de liberación, sin embargo, tuvo tropiezos. Algunos amos fueron denunciados por sus intentos de retener a los menores hijos de los esclavos con el pretexto de haber comprado sus contratos hasta los 18 años y piden al prefecto hacer cumplir la ley de abolición (“Vampiros!», El Comercio, 22 de enero de 1855: 4). Otros amos recurrieron a medidas extremas para retener a los antiguos esclavos: así en una panadería de Pescadería se produjo un incendio y allí la autoridad encontró cinco hombres encadenados que fueron salvados de perecer entre las llamas: tres eran antiguos esclavos y dos, chinos traídos a contrata. El propietario, José Manuel Ayulo, fue multado («Policía. Ocurrencias», El Comercio, 2 de marzo de 1855: 3, y «Multas», El Comercio, 2 de marzo de 1855: 2). Era intendente de la policía Juan Bustamante, quien años después encabezaría la lucha por las reivindicaciones campesinas en Puno, cosa por la que fue ejecutado bárbaramente en 1869.

La liberación siguió el procedimiento administrativo de otorgar cartas de libertad. Los antiguos esclavos debían ser registrados por una Junta de Inscripción, y estaban obligados a trabajar en la cosecha de ese año, si no querían ser considerados vagos y enviados a las islas de Chincha a la extracción de guano (Reglamento de 23 de enero de 1855). En la prensa se manifestaron voces que arguyeron que los liberados no estaban "preparados» para ser libres, lo que motivó la respuesta sarcástica de los partidarios de la abolición. La furia de los antiguos amos se calmó un tanto cuando el Estado acordó pagarles una indemnización por cada esclavo liberado. 


\section{Las secuelas de la esclavitud}

La abolición de la esclavitud de 1854 dio sobre el papel la nacionalidad peruana a la población negra, y aparentemente otorgaba la condición de ciudadanos a los varones liberados. Pero los hacendados y otros beneficiarios de la esclavitud se sintieron agraviados ante la perspectiva de ser ciudadanos iguales a sus ex esclavos. Felipe Pardo y Aliaga (1806-1868), reconocido escritor del costumbrismo, dio en su teatro voz a los esclavos para tipificar el habla popular marcado por las lenguas africanas. Asimismo, representó los agravios de la esclavitud a través del discurso de las ex esclavas (Velásquez 2005: 117-122). Cabe puntualizar, sin embargo, que esa voz femenina en el teatro no aparecía como un peligro para la esfera de poder que importaba a los grandes estadistas, pues las mujeres de la raza que fuere no podían ser ciudadanas ni ejercer el sufragio, y sus expresiones podían en todo caso suscitar compasión, sentimiento que básicamente parte de un rasgo de superioridad en quien la siente. Pardo, en cambio, satirizó la igualdad ciudadana que iban a alcanzar los ex esclavos en versos que dedicó a su hijo con motivo de haber alcanzado la mayoría de edad: «Dichoso hijo mío, tú,/ que veintiún años cumpliste;/ dichoso que ya te hiciste/ ciudadano del Perú./ Este día suspirado/ celebra de buena gana,/ y vuelve orondo mañana/ a la hacienda y esponjado,/ viendo que ya eres igual,/ según lo mandan las leyes,/ al negro que unce tus bueyes/y al que te riega el maizal». Los varones liberados de la esclavitud sí resultaban amenazantes para personas como Pardo y Aliaga que creían en una sociedad rígidamente estratificada cuya cima debía estar ocupada por él y sus pares. Por ello una ciudadanía que comprendiera a los negros que trabajaban en las haciendas de su propiedad era algo que solo les suscitaba desdén y sátira, y no estaban dispuestos a socializar a sus descendientes según principios igualitarios. Merece una reflexión el hecho de que posiblemente el hijo a quien estaban destinados estos versos fuera Manuel Pardo y Lavalle que sería presidente del Perú y líder del Partido Civil.

La abolición, pues, no convirtió automáticamente en ciudadanos de pleno derecho a los esclavos liberados. Las elecciones a la Convención Nacional de 1855 se realizaron mediante el sufragio universal masculino por primera y última vez en el país, pues no se exigió profesión, ni un nivel de renta, ni saber leer y escribir. Conservadores como Atanasio Fuentes y Evaristo Gómez Sánchez satirizaron esas elecciones y se escandalizaron de la compra de votos, cuyos vendedores habrían sido los libertos, esto es, los ex esclavos. En específico Fuentes aludía al proceso de abolición y cambio de signo político exclamando: "QQué libertad más negra!» (Basadre 2005: IV, 845).

La opinión ilustrada contraria a la igualdad se manifestó en los diarios denunciando las ocasiones en que presuntos ex esclavos asediaban a los ciudadanos reputados decentes en las calles, y especialmente a las mujeres blancas (Velásquez 2005: 70-71). El comportamiento acosador es atribuido por la prensa solo a los hombres liberados, si bien era algo en que incurrían los hombres de toda condición. Asimismo, los antiguos amos no cesaron de quejarse y llegaron a acusar a sus antiguos subordinados de "comunismo" porque estos buscaban mantener el acceso a la tierra que habían trabajado durante los años de su servidumbre:

Deseosos algunos hacendados de restablecer el orden en sus fundos, han tratado de despedir a sus antiguos esclavos, que entregados al ocio y la rapiña daban mal ejemplo a los demás; pero la medida no ha producido buen efecto, porque en muchas haciendas los hombres libertados, se han resistido a su cumplimiento, haciendo entender a sus patrones, que ellos también son dueños de la tierra para continuar en el goce que antes tenían de labrarla y cosecharla para sí, en aquella parte que la liberalidad de sus antiguos amos se lo permitía («Reforma», El Comercio, 5 de febrero de 1855).

Era impensable que los recursos que entonces controlaba el estado peruano se dirigieran a los ex esclavos, de cuyo trabajo se habían beneficiado sus dueños. Por el contrario, fueron los ex amos los que recibieron importantes sumas a título de indemnización por haber perdido «su capital». Los ex esclavos solo tuvieron la oportunidad de trabajar en los mismos oficios que habían ejercido como esclavos, muchos, especialmente las mujeres, en la servidumbre doméstica. Cuando en 1859 el pintor Francisco Laso dio a conocer su lienzo "La lavandera», habían pasado unos años desde que se había dado la abolición. Una cierta melancolía envuelve el retrato de esta mujer negra: quizá en parte había sido esclava durante la mayor parte de su vida, si es que nació antes del 28 de julio de 1821, o había 
estado limitada por la condición de liberta. En el momento en que Laso la pinta es una persona libre, pese a todas las cortapisas que existían para el ejercicio de dicha libertad en una sociedad en que el color de la piel era una marca que definía el status social y económico, y las pocas oportunidades que tenía de salir de la esfera de la servidumbre doméstica. Sin embargo, se trata de un retrato de cuerpo entero, algo que solo se empleaba en lienzos de grandes personajes, quizá así Laso reivindicó a las lavanderas acuclilladas al borde de los ríos que décadas antes había dibujado Rugendas ${ }^{2}$.

El fin de la esclavitud legal no significó el fin de la trata de personas en el territorio peruano. Ya existía desde 1849 una "migración» de culíes chinos para trabajar en las islas guaneras, las haciendas y el servicio doméstico. En 1854 los culíes traídos al Perú sumaban 583, pero al año siguiente su número se cuadriplicó (2236) y se siguió incrementando en los años siguientes (Rodríguez 2005: 447). Vinieron sometidos a contratas que los obligaban a servir durante años. Por otra parte, se traía "cholitos», es decir, menores de edad que quedaban adscritos a hogares en las ciudades como sirvientes domésticos sin ningún derecho y eran sometidos con frecuencia a maltratos (Ragas 2016). La contrata de culíes y el tráfico de menores traídos de la sierra como sirvientes domésticos constituyeron señaladamente actividades que contribuyeron a ahondar la impronta de desigualdad en las relaciones sociales vigentes en el ámbito privado y público. Otro medio para someter a los trabajadores a una relación obligada fue la deuda, que incluso se transmitía de padres a hijos, y que fue empleada en las haciendas para impedir su libre circulación. A partir de ahí se desarrollaron formas de conseguir trabajadores como el enganche, el peonaje por deudas, la servidumbre, que coartaban la libre circulación de las personas y su autonomía, lo que propició situaciones en que la trata de personas pudo prosperar, aunque la esclavitud hubiera desaparecido como institución legal. Nuestra época no se ha visto libre de la mercantilización de la persona humana. Las noticias esporádicas, las denuncias que acaban en páginas de sucesos, indican la persistencia de formas de esclavitud en

2 Pueden verse las imágenes de lavanderas en Rugendas, 1975, láminas; y el lienzo La lavandera, de Francisco Laso en Archivo Digital del Arte Peruano: http://www.archi.pe/public/index.php/foto/index/3037 (consultado 13 de mayo de 2018). zonas de dinámica explotación capitalista como los campamentos mineros, y en el sector terciario, especialmente en el servicio doméstico. Los afectados son principalmente menores y mujeres a los que se obliga a todo tipo de trabajos y a ejercer la prostitución y la mendicidad. Aunque existe un plan nacional contra la trata de personas en el Perú ${ }^{3}$, el hecho es que en el año 2017 se advirtió un incremento del 24 por cien de casos de trata con respecto al $2016^{4}$.

\section{Bibliografía}

Aguirre, Carlos (1990). "Cimarronaje, bandolerismo y desintegración esclavista. Lima 1821-1854», C. Aguirre y Charles Walker, eds., Bandoleros, abigeos y montoneros. Criminalidad y violencia en el Perú, siglos XVIII-XX: 137-178: Instituto de Apoyo Agrario, Lima.

Aguirre, Carlos (1993). Agentes de su propia libertad. Los esclavos de Lima y la desintegración de la esclavitud: 18211854. Fondo Editorial de la Pontificia Universidad Católica, Lima

Aranda, Ricardo (1890-1911). Colección de los tratados, convenciones, capitulaciones, armisticios y otros actos diplomáticos y políticos. 8 vols.: Imprenta del Estado, Lima.

Arona, Juan de (1884). Diccionario de peruanismos. Librería Francesa Científica J. Galland, Lima.

BAsAdre, Jorge (2005). Historia de la República del Perú. $8^{\text {a }}$ edición. 16 tomos. La República. Lima.

Blanchard, Peter (1992). Slavery and Abolition in Early Republican Peru: Scholarly Resources. Wilmington, Delaware.

Carrasco, Eduardo (1840) Calendario y guía de forasteros de la república peruana para el año de 1841. Imprenta Félix Moreno. Lima

Centurión Vallejo, Héctor (1954). Esclavitud y manumisión de negros en Trujillo. Trujillo.

Cosamalón Aguilar, Jesús (2014). «Los últimos esclavos. Africanos en Lima según el censo de 1860». En Los afrodescendientes en el Perú republicano. 9-44, Eduardo

3 Perú, Ministerio del Interior, «Plan nacional de acción contra la trata de personas 2011-2016", http://spij.minjus.gob.pe/Graficos/ Peru/2011/octubre/19/DS-004-2011-IN.pdf (consultado el 4 de noviembre de 2018)

4 «Lucha contra la trata de personas», El Peruano, 27 de julio de 2017, en: https://www.elperuano.pe/noticia-lucha-contra-trata-personas-68368.aspx (consultado el 4 de noviembre de 2018). 
Huárag Álvarez, comp.: Pontificia Universidad Católica del Perú, Instituto Riva-Agüero, Lima.

Dieguez Deza, Victoria Bienvenida (2013). «La rebelión de esclavos en Trujillo de 1851", (Tesis) Universidad Nacional de Trujillo. Facultad de Ciencias Sociales. Escuela Académico Profesional de Historia.

Hunefeldt, Christine (1992). Lasmanuelos, vida cotidiana de una familia negra en la Lima del s. XIX. Una reflexión histórica sobre la esclavitud urbana. Lima: IEP.

Jouve Martin, José R. (2014). The Black Doctors of Colonial Lima: Science, Race, and Writing in Colonial and Early Republican Peru, McGill-Queen's University Press, Montreal, Kingston, Londres e Ithaca.

LAVALlÉ, Bernard (1998). «Crisis agraria y cambios en la relación esclavista: Trujillo (Perú) durante el último siglo colonial», Jahrbuch für Geschichte Lateinamerikas, vol. 35, no 1: 45-72.

Markham, Clements (1991). Markham in Peru. The Travels of Clements R. Markham, 1852-1853. Peter Blanchard, ed. University of Texas Press, Austin.

Mejías Navarrete, Elizabeth (2007). «La esclavitud doméstica en sus prácticas: los esclavos y su constitución en personas. Chile 1750-1820", Fronteras de la historia, no 12: 119-150.

Pando, José María (1833). Reclamación de los vulnerados derechos de los hacendados de las provincias litorales de la provincia de Lima. Lima: Imprenta Rep. de J. M. Concha.

Paredes, José Gregorio (1832). Calendario y guía de forasteros de Lima para el año de 1833. Imprenta de J. M. Masías, Lima.

Paredes, José Gregorio (1833). Calendario y guía de forasteros de Lima para el año de 1834: Imprenta de J. M. Masías, Lima.

Paredes, José Gregorio (1836). Calendario y guía de forasteros de Lima para el año de 1837. Imprenta de José Masías, Lima.
Paredes, José Gregorio (1837). Calendario y guía de forasteros de Lima para el año de 1838.: Imprenta de José Masías, Lima.

Pareja Pflucker, Piedad (2015). Del antiguo esplendor de Lambayeque: casa de Castillo (siglo XVIII) y casa Muga (siglo XIX). Edición del autor, Lambayeque.

Ragas, José (2016). «Remembering Captive Bodies: Indigenous Child Labour and Runaway Ads», Open Democracy. https://www.academia.edu/28435240/ Remembering_Captive_Bodies_Indigenous_Child_ Labour_and_Runaway_Ads Consultado el 13 de mayo de 2018.

Rico, Gaspar (1813). Proyecto relativo al comercio, suerte y servidumbre de los esclavos inclinado a su transición oportuna a libres durante el tiempo que debe continuar la introducción en territorios españoles. Cádiz: Imprenta Tormentaria.

Rodríguez Pastor, Humberto (2005). «Abolición de la esclavitud en el Perú y su continuidad», en Investigaciones Sociales, $\mathrm{N}^{\circ} 15$ : 441-456.

Rugendas, Johann Moritz (1975). El Perú romántico del siglo XIX (estudio preliminar de José Flores Araoz). Carlos Milla Batres, Lima.

Tardieu, Jean Pierre (2005). El decreto de Huancayo. La abolición de la esclavitud en el Perú. Fondo Editorial del Congreso del Perú, Lima.

Velázquez Castro, Marcel (2005). Las máscaras de la representación el sujeto esclavista y las rutas del racismo en el Perú (1775-1895). Fondo Editorial: Banco Central de Reserva del Perú, Lima.

Vollmer, Günther (1967). Bevolkeringspolitik und Bevolkerung strucktur um Vize-Konigreiche Peru zur Ende del Kolonialzeit. Verlag Gehlen.

Abreviaturas usadas

ARL = Archivo Regional de Lambayeque, Chiclayo

AGN = Archivo General de la Nación, Lima

$\mathrm{BNP}=$ Biblioteca Nacional del Perú, Lima 